\title{
Nanoparticles and Restorative Dentistry - A Review
}

\author{
L Sampath Kumar ${ }^{1}$ \\ Mechanical Engineering Department \\ Sir M. Visvesvaraya Institute of Technology line \\ Bangalore- 562 157, India.
}

\author{
V. Shantha ${ }^{2}$ \\ Mechanical Engineering Department \\ Sir M. Visvesvaraya Institute of Technology line \\ Bangalore- 562 157, India.
}

\author{
Chandrashekhar Naik ${ }^{3}$ \\ Department of Bio-Technology ${ }^{3}$ \\ Sir M. Visvesvaraya Institute of Technology, Bangalore- 562 157, India.
}

\begin{abstract}
Irrespective of the research field nanotechnology is very interesting area. Before studying about synthesis of nanoparticles, evaluation of its properties, uses and applications of nanoparticles in different fields, knowing history is very important. In this regards authors have tried to brief the historical development about the nanoparticles used in restorative dentistry with respect to the classification of materials. Nanotechnology includes controlled scaling down of materials at the nanometer scale, where the properties of the materials are one of a kind, sudden and novel when contrasted with their mass partners. Along these lines, designed nanoparticles are tremendously being connected as detecting tests, imaging, tranquilize conveyance, theranostics, battling infections like malignancy and additionally battling microbial pathogens. Alongside the biomedical applications, there are set up employment of nanoparticles for mechanical applications and business items, due to their inborn physicochemical and synergist properties, and enormous surface-region to-volume proportions.
\end{abstract}

Keywords: - Nanoparticles, restorative dentistry,

\section{INTRODUCTION}

The term dentistry originates from odontology which was gotten from Ancient Greek word "odoús" which signifies "tooth"- the investigation of the structure, improvement, and anomalies of the teeth. The utilization of nanotechnology is a long way from being new. For instance, it was utilized around $2600 \mathrm{BC}$ in colors to grant shading to strands and textures [1]. Another model can be found in Middle Age houses of worship, where recolored glass craftsmen used nanoscopic scale (or nanoscale) gold and silver particles to grant ruby red and profound yellow shading to window boards [2]. Another precedent is the Damascus steel delivered by the twelfth to the eighteenth century Middle Eastern metalsmiths, which incorporates cementite nanowires inside carbon nanotubes [3]. Around then, they had no real way to watch the nanostructures they made. All the more as of late, carbon dark has been utilized since 1910 to fortify tires, without realizing that it was the communication among elastic and the nanoscale carbon dark particles that granted the tires with expanded hardness, quality, scraped spot, and tear obstruction [4]. The word nanotechnology was utilized without precedent for 1974 by Norio Taniguchi in reference to machining and completing dimensional resilience's for semiconductor forms [5]. It was taken from the Greek word for a smaller person and means a billionth of a unit. Notwithstanding, it was simply after the improvement of the checking burrowing magnifying instrument in 1981 by IBM specialists Gerd Binning and Heinrich Rohrer [6] that advancement truly commenced; it was currently conceivable to watch matter at the nanoscale. They were granted a Nobel Prize in physical science in 1986 for this revelation, which exploits the quantum wonder displayed by conductor and semiconductor materials at the nanoscale. At that point, fullerenes were found in 1985 by Harold Kroto, Robert Curl, and Richard Smalley [7], who won a Nobel Prize in science in 1996 for this accomplishment. The main controlled development of carbon nanotubes is credited to Sumio Lijima and his associates in 1991 [8].

Restorative dentistry was begun at the season of Egyptian time at the same time, stayed undeveloped until the eighteenth century. The prior dental prosthesis was produced using human teeth which are hard to obtain and costly as well, creature teeth are hand eroded effectively because of nature salivary specialists and cut to human size and shape. John Greenwood utilized hippopotamus teeth for George Washington's denture [9-11]. Porcelain was presented by Alexis Duchateau, for dentistry application in 1774 is a standout amongst the most critical memorable advancements in dentistry. A few reports were found in 1728 Fuchard, a French dental specialist, utilized heated veneer [12].

Types of Dental Restorations [13]

The types of restorations involved include:

- Simple Feldspathic Veneers

- Porcelain Jacket Crowns and Bridges

- Metal Ceramic Crowns and Bridges

- Inlays and Onlays

- Implant Superstructures.

These systems are shown schematically in Figure a, b, c, \& d. 
Fig. a

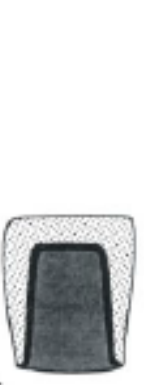

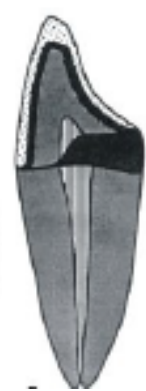

Fig. b
Fig .c

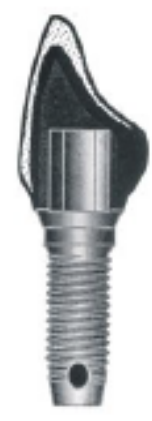

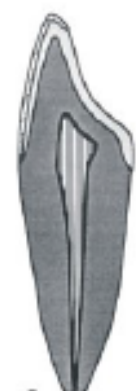

Fig. d

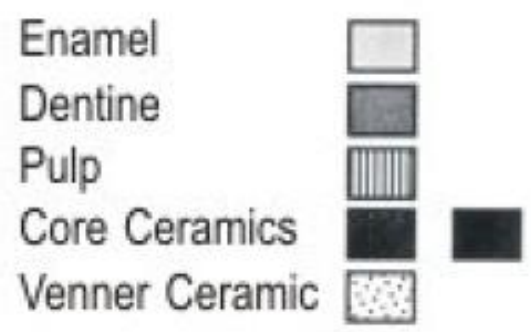

Fig .a Shows in Ceram crown with standard crown design.

Fig .b lateral view of In Ceram crown demonstrating underlying tooth structures.

Fig. c lateral view of ceramic crown on a titanium implant.

Fig. d porcelain veneer resin bonded to tooth enamel.

Nature has organized complex bio minerals in the most ideal manner from the miniaturized scale to the nanoscale and nobody can yet join natural and physical properties to get perfect structures. Also, no engineered material can be smart enough to react to outside upgrades and respond like nature made tissues [13]. There are various potential choices to make brilliant materials for the development and emulating of nature (Table 1$)$.

TABLE .1 ALTERNATIVES FOR THE CREATION OF SMART MATERIALS FOR DENTAL APPLICATIONS [14].

\begin{tabular}{|l|l|}
\hline \multicolumn{1}{|c|}{ Choice } & \multicolumn{1}{|c|}{ Explanation } \\
\hline Material Synthesis & $\begin{array}{l}\text { Creating manufactured materials } \\
\text { coordinating morphology and properties } \\
\text { like common dental tissues }\end{array}$ \\
\hline $\begin{array}{l}\text { Biomimetic } \\
\text { Approaches }\end{array}$ & $\begin{array}{l}\text { To supplant lost dental tissues pursue } \\
\text { nature's standards an creating } \\
\text { biomaterials looking like their } \\
\text { properties near the supplanting tissues. }\end{array}$ \\
\hline Tissue Engineering & $\begin{array}{l}\text { Utilization of regenerative drug and } \\
\text { tissue building approaches for } \\
\text { supplanting the lost dental tissues by } \\
\text { recoveries }\end{array}$ \\
\hline
\end{tabular}

The unbroken, material sense, mist, flow, the capacity of transfer, exterior, and sense, compactness, vital stiffness, poorest, and physical character of many components are altered by the size and virtue of their basic particles [15]. Nanotechnology involves controlled miniaturization of materials at the nanometer scale, where the properties of the materials are unique, unexpected and novel, when compared to their bulk counterparts. Therefore, engineered nanoparticles are enormously being applied as sensing probes, imaging, drug delivery, theronostics, combating diseases like cancer [16-17] and or fighting microbial pathogens [18-20]. Beyond biomedical applications, there are established uses of nanoparticles for industrial applications and commercial products, due to their intrinsic physicochemical and catalytic properties, and large surface-area-to-volume ratios [20].

\section{CLASSIFICATION OF MATERIALS}

The materials utilized in dentistry are of four kinds, they are Metals, Ceramics, Polymers, and Composites. Utilitarian execution, style, and biocompatibility are three significant necessities for dental helpful materials [21].

\section{METALS}

Metals are the first classification of materials used in dentistry since many centuries. Hear is a brief of some metal materials and its alloys used in dentistry.

\section{A. Gold}

Among metals Gold is the most seasoned dental remedial material, have been utilized for dental fixes for over 4000 years. In 1400 Joannes Arculans referenced that gold leaf was utilized by dental specialist in those days [22-23] Porcelaincombined to-metal rebuilding efforts were boundless innovation since 1960[24] Gold is an ideal respectable metal for the supplanting of lost tooth with impeccable natural and mechanical properties aside from style and can be cold welded at room temperature. Gold is most grounded and the strongest among every single helpful material with warm development and constriction coefficient is like that of characteristic teeth and consequently, there is no harm to the reclamation with the utilization of hot or freezing substances [25].

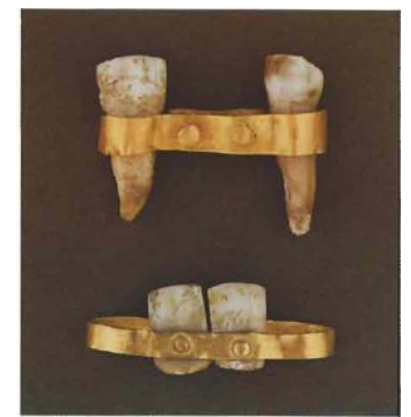

Fig .1 shows outline of two Etruscan dental prostheses made by passing meager segments of gold round teeth on each side of the room from which a tooth or teeth had been lost and riveting the strip in order to hold the substitute teeth set up. In one case, the projection teeth are available, yet the counterfeit tooth is lost, and in the other case, the two substitute teeth, segments of a creature tooth, remain [26].

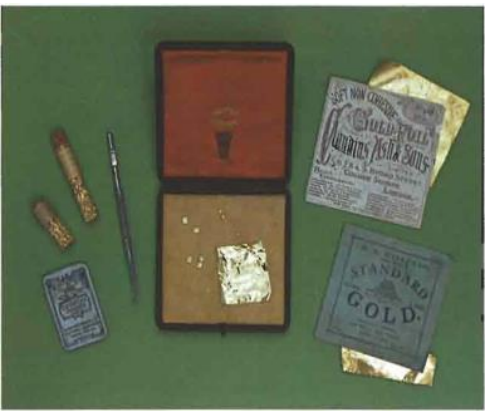

Fig . 2 shows here are nevertheless a portion of the numerous types of gold accessible for dental fillings at the turn of this century. The foil was controlled with the tweezers and kept to hand on the chamois cowhide 'gold cushion'[26]. 


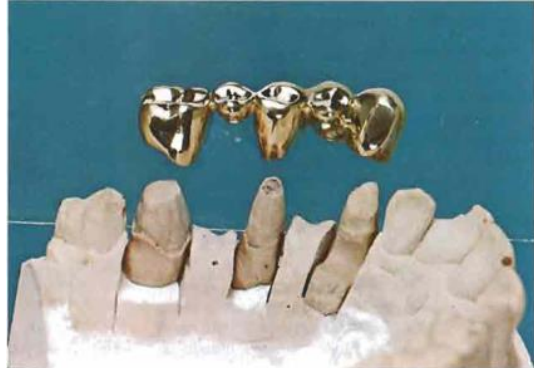

Fig .3 Shows cutting edge cast gold combinations connect with the working model of the patient's teeth [26]

Numerous investigations have been completed to improve the mechanical properties of the $\mathrm{Au}$ combinations containing copper $(\mathrm{Cu})(\mathrm{Au}-\mathrm{Cu}-\mathrm{Pd}$ [27-28], $\mathrm{Au}-\mathrm{Ag}-\mathrm{Pd}-\mathrm{In}$ [29], $\mathrm{Au}-$ $\mathrm{Cu}-\mathrm{Zn} \mathrm{[30],} \mathrm{Au}-\mathrm{Cu}-\mathrm{Zn}-\mathrm{Ag}$ [31], and $\mathrm{Au}-\mathrm{Ag}-\mathrm{Cu}-\mathrm{Pd}$ [32] compounds), with the primary spotlight on the microstructural changes created by warmth treatment.

\section{B. Silver and its Alloys}

Dental amalgam is a blend of silver combination (silver 40 $70 \%$, tin $12-30 \%$ and copper $12-24 \%$, and once in while zinc up to $1 \%$, palladium $0.5 \%$ or indium $0-4 \%$,) with mercury. At the point when both are blended, a synthetic response will happen and frame dental amalgam and the response among composite and mercury is named as amalgamation response. Albeit a few types of mercury are dangerous, the mercury in amalgam is synthetically bound to different metals to make it stable and consequently it is the most secure metal for dental applications as oxidation preventer while fabricating [33-37], represses consumption [38], and causes postponed development [39-40]. Indium blended with high copper amalgam shows a decrease in the jerk and expands quality. Palladium diminishes stain and consumption [39]. Dental amalgam is a standout amongst the most flexible helpful materials utilized in dentistry. It establishes around $75 \%$ of every single therapeutic material utilized by dental specialists. It has filled in as a dental reclamation for over 200 years [41]. Dental amalgam obviously was first utilized by the Chinese. Su Kung (659 AD) referenced the utilization of a blend in the Material Medica.[42]. In Europe, Johannes stokers, a city doctor in Ulm, Germany, suggested amalgam as a filling material in 1528 [43]. One increasingly major authentic reference to silver-mercury amalgam was made in France; Traveau depicted a "silver glue" filling material in 1826 and delivered amalgam by blending the silver coins with mercury [44]. J. Cultivate Flagg distributed the consequences of his research center tests and 5-year clinical perception of new composites with $60 \%$ of silver and $40 \%$ of tin as real constituents in 1881 which was completed 15 years sooner by G.V. Dark [45-46]. S.S. White produced the principal business combination wealthy in silver, True Dentalloy (1900), in which gold was supplanted by copper. A combination with the organization of $68.5 \%$ silver, $25.5 \%$ tin, $5 \%$ gold, $1 \%$ zinc, was an engineer by joining the standards of depression plan, augmentation of the pit into "invulnerable" territories which leads the Black propelled amalgams into present day times [47-49].

Regardless of a superior comprehension of the materials and science, and late upgrades in physical properties, no material has been discovered that is perfect for any dental application [50]. For instance, silver amalgam has been utilized for dental reclamation for over a century; be that as it may, there has been a noteworthy worry about mercury danger from the amalgam rebuilding efforts for a long time [51-55]. Another serious issue is the shade of amalgam for tasteful contemplations and elective materials are being looked to supplant [56-58]. The composite helpful materials have promising feel anyway these materials are method delicate and mechanical properties are not comparable to of amalgams [59].

Gallium is another Silver combination with the organizations of Silver - half, Tin $-25.7 \%$, Copper $-15 \%$, Palladium $-9 \%$ and follows $-0.3 \%$. The softening temperature of Gallium can be smothered underneath room temperature with the expansion of fitting measures of Indium and Tin. This fluid would then be able to be triturated with silver-tin-copper combination powder in a similar manner as dental amalgam. Noteworthy measures of Palladium are added to the combination powder in the present business arrangements to improve erosion properties. The present creation of gallium compound comes in powder which is been showcased in Japan known as Gallium combination GF by Tokuriki Houston [60]. The utilization of gallium composites as a dental helpful was proposed in 1928 with concern about the conceivable danger of mercury-containing amalgam has stirred enthusiasm for less mercury options. Early gallium compounds extended too much, especially whenever tainted by dampness. In 1994 a non-palladium gallium compound (Galloy) was presented with a case of lower setting extension, in examination with Dispersalloy controls, Galloy rebuilding efforts were related with over the top postoperative affectability and a high frequency of tooth cusp crack [61].

\section{Titanium}

Titanium (articulated/tai' teiniem) was found in England by William Gregor in 1791 and named by Martin Heinrich Klaproth for the Titans of Greek folklore [62]. The utilization of titanium and titanium amalgams for therapeutic and dental applications has expanded drastically as of late. Titanium can be alloyed with different components to change its qualities, principally to improve the physical and mechanical properties, for example, quality, high-temperature execution, creep obstruction, weldability, reaction to maturing heat medications, and formability [63-65]. Among the various properties of titanium, the biocompatibility is the greatest down to earth angle and it is because of the presence of titanium oxide ( $\mathrm{TiO} 2)$ layers, which are normally framed in oxygen-containing conditions. It is additionally conceivable to be created with different fake systems, e.g., anodizing [6667]. Titanium is generally latent, erosion obstruction metal in the light of its meager (roughly $4 \mathrm{~nm}$ ) surface oxide layer. Studies have demonstrated that Titanium promptly adsorbs protein like egg whites, laminin, glycosaminoglycans, collagenase, fibronectins, supplement proteins, fibrinogens, and so forth from the natural liquids [62]. Titanium is a thermodynamically receptive metal as a result of its generally negative reversible potential in the electrochemical arrangement [68] 
In the mid-1960s, William Buehler alongside Frederick Wang at the U.S Naval Ordnance Laboratory found the shape memory impact combination of nickel and titanium, which can be viewed as a leap forward in the field of shape memory (Buehler et al. 1967). This amalgam was named Nitinol [also known as a shape memory combination (SMA), the primary endeavors to misuse the capability of $\mathrm{NiTi}$ as an embed material were made by Johnson and Alicandri in 1968 (Castleman et al. 1976). The utilization of NiTi for therapeutic applications was first detailed during the 1970s [69-71]. The unordinary properties of this brilliant material are gotten from the two gem structures that can be between changed over by changes in temperature or weight. At temperatures between around 0 and $100^{\circ} \mathrm{C}$, there are two significant stages or precious stone structures of NiTi that can be alluded to as the high temperature and low-temperature stage, or as austenite and martensite, separately. The austenite stage has the symmetry of a shape and is described by hardness and unbending nature [72-73]. In dentistry, the material is utilized in orthodontics for sections and wires associating the teeth. When the SMA is set in the mouth its temperature raises to encompassing body temperature. This makes the Nitinol contract back to its unique shape applying a steady power to move the teeth. These SMA wires don't be retightened as regularly as they can contract as the teeth move, dissimilar to traditionally treated steel wires. Furthermore, Nitinol can be utilized in endodontics, where Nitinol records are utilized to clean and shape the root trenches during the root channel strategy [74].

\section{Stainless Steel}

Stainless steels have been effectively utilized in orthopedics and dentistry for over a century till the presentation of vanadium careful steel by Sherman in 1912 when it was discovered that flexibility and pliability were not found in different steels; nonetheless, the vanadium steel had poor biocompatibility [75]. In 1926, the $18-8-18 \%$ chromium (Cr)$8 \%$ nickel $(\mathrm{Ni})$ and austenitic treated steel was presented in light of the fact that it was more grounded and more consumption safe in saline situations. Strauss licensed a variety of this 18-8 steel that additional $2 \%$ to $4 \%$ molybdenum (Mo) and made it much increasingly safe in acidic and chloride situations [76]. Chromium and molybdenum are included for consumption opposition and huge measures of nickel are added to settle the austenitic structure. Extra regular alloying components incorporate silicon, manganese, niobium, titanium, and carbon. Albeit austenitic steels are not hardenable by warmth medicines, the huge measure of malleability enables them to experience significant virus working before break [77]. Treated steel is a minimal effort material which offers great erosion opposition, pliability and the capacity to work solidify during the pleating procedure and it was proposed by clinicians tempered steel crowns are simpler to place crying youngsters when contrasted and amalgam [78]. In any case, a few professionals recommend that hardened steel are too tedious to fit, unseemly for some applications, hard to control and not tastefully satisfying in the oral depression while rebuilding [79].

\section{IV.CERAMICS}

Ceramics are the second broad classification of material used in dentistry step by step development of ceramics was quoted in history are as follows, the first-generation ceramics were failed in dentistry due to high fracture rate. With higher density and smaller grains, a second generation of ceramics was developed in the late 1980s and the fracture rate for second generation of alumina was decreased to less than $5 \%$ [80]. Finally, today a third generation of ceramic components is available, characterized by high purity, full density and finer microstructure. In the last few decades, there have been remarkable advances in the mechanical properties and methods of fabrication of ceramic materials [81-83]. The word Ceramic began from the Greek expression "keramos" signifying "potter or earthenware" [84].

In the mid-1700s, numerous European rulers were spending gigantic wholes bringing in porcelain from China and Japan. Figure 4, from Schloss Charlotte burg in Berlin, is illustrative of simply little parts of one of these accumulations. The gathering of Augustus III of Saxony was maybe the biggest and is currently in plain view at the Zwinger Museum in Dresden, his previous castle. Such movement drove China to be portrayed as being 'the draining bowl of Europe'. Among 1604 and 1657 alone, more than three million bits of Chinese porcelain came to Europe [85]

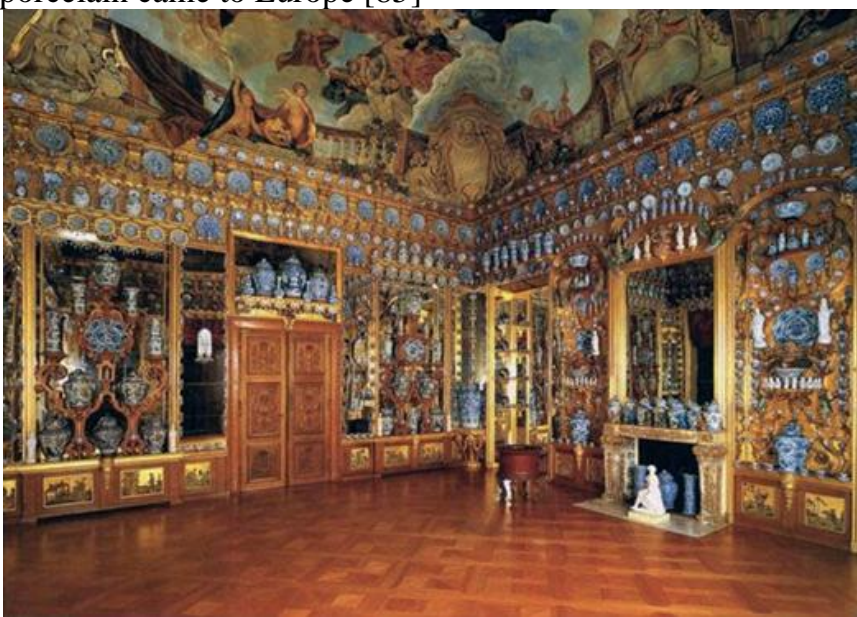

Fig .4 Schloss Charlotte burg in Berlin is illustrative of simply little segment of one of the broad porcelain accumulations mainstream with European sovereignty [86].

Characterization of ceramic based materials

Dental ceramics can be arranged dependent on either:

a) Uses or signs (for example foremost, back crown, facade, post and center, fixed prosthesis, earthenware recolor, coat)

b) Composition

c) Principal precious stone grid stage (silica glass, leucite-based feldspathic porcelain, leucite-based glass ceramic, Lithia disilicate-based glass-ceramic, leucite disilicate-based glass-artistic, aluminous porcelain, alumina, glass-implanted alumina, glassimbued spinel, glass-injected alumina/zirconia)

d) Processing technique (throwing, sintering, fractional sintering, and glass invasion, slip throwing and 
sintering, hot isostatic squeezing, CAD-CAM processing, and duplicate processing)

e) Firing temperature (ultralow intertwining, low combining, medium melding, and high intertwining)

f) Microstructure (formless glass, crystalline, crystalline particles in the grid)

g) Translucency (misty, translucent, straightforward)

h) Fracture opposition (low, medium, hard)

i) Abrasiveness (examination in respect to veneer, against tooth finish)

For the most part, tooth to tooth wear will result amidst teeth and recovery contact which results in ordinary unavoidable wear of tooth. Teeth wear will be more due to inside restoration of oral cavity, especially in case of opposing ceramic restorations [87-90]. In case of opposing ceramic restorations the rate of tooth surface is more [91]. Wear of entire tooth is also possible and it leads to numerous problems such as damage to opposing enamel structure, loss of occlusal vertical dimension, problems in mastication, temporomandibular joint problems, hypersensitivity, and esthetic impairment [92-94]. Tooth wear occurs due to interaction between erosion, attrition, and abrasion, whereas abfraction may potentiate the process - is the definition for tooth wear by Shellies and Addy [89], one or the other mechanisms will interact simultaneously which majorly leads in occlusal and cervical wear [95-96] Erosion, Attrition, Abrasion, and Abfraction are few classifications of tooth wear based on the morphological and etiological factors [9798].

Bio ceramics, (for example, alumina, zirconia, Hap, and so forth.) are principally utilized in orthopedic and dental reparation. All through mankind's history, Alumina is the main strong oxide type of aluminum $\left(\mathrm{Al}_{2} \mathrm{O}_{3}\right)$ likewise called Aluminum oxide has innovatively viable artistic material [99]. Aluminum oxide was first presented during the 1970s, with a break rate as high as $13 \%$ [100]. Original earthenware production was bombed in dentistry because of high break rate. With the higher thickness and little grains, the second era of earthenware production was created in the late 1980s and the crack rate for the second era of alumina was diminished to fewer than 5\% [101]. At long last, today the third era of artistic parts is accessible, portrayed by high virtue, full thickness, and better microstructure. Over the most recent couple of decades, there have been striking advances in the mechanical properties and strategies for the creation of fired materials [102-104]. A few sorts of earthenware production were created because of interest for very tasteful, biocompatible and dependable remedial materials by specialists and patients made analysts move towards sans metal rebuilding in the dental field from a most recent couple of decades [104]. Metals and earthenware production are advanced and feel can be expanded by silicate and glass pottery. Aluminum and Zirconium oxide earthenware production are utilized as a center material for crowns and fixed dental prostheses (FDPs) in light of their high qualities [105]. Zirconia has a lower disappointment rate then silicate or alumina systems [106] Bilayer zirconia/facade reclamations results in early chipping/crack were seen in oral working [107]. Contradicting dentition wear pottery setting over the occlusal surfaces ought to be maintained a strategic distance from [108]. Dental earthenware production is quickly developing exploration region; the stylish appearance of artistic rebuilding efforts is because of the surface of the reclamation, which is controlled by the surface completion and Modifications of clay materials are prescribed to deliver progressively tough fired regarding wear opposition and to limit the undesired impacts [109]. Therapeutic materials are to be profoundly stylish, biocompatible and dependable remedial is the fundamental necessity by specialists and patients in this perspective a few kinds of fired reclamation materials have been created [110].

\section{CONCLUSION}

Gold and Gold Alloys are having a low softening point, high bond quality which uses gold in patching. It is high lengthening as cast or solidified, impeccable biocompatible, normal tasteful appearance with great mechanical properties. It is strongest among all the restorative materials. However mercury is available in Dental Amalgum, it will artificially tie to different metals to make it steady and safe for use in dentistry. Thus it is steady, hinders erosion, postpones extension, lessens creep, and builds quality, and decreases stain and consumption. Thus, Dental amalgam is utilized as remedial materials in dentistry around $75 \%$ among every single other metal for over 200 years. Stainless steel and amalgams are overwhelming gold in light of their higher firmness, increasingly tasteful; likewise due to their low costs, great mechanical properties, and satisfactory erosion obstruction in the oral condition be that as it may, Stainless steels are ideal versatility contrasted and gold wires. Titanium and titanium alloys, in light of their physical and compound properties, reasonable for dentistry. Titanium shows low poisonous quality, incredible solidness with low consumption rates and great mechanical properties contrasted with different metals. The mix of high solidarity to-weight proportion, Lightweight, magnificent mechanical properties, consumption opposition, Biocompatible, Non-harmful, Longenduring, Non-ferromagnetic, the joining of bone with fake embed, Cost-productive and Long range accessibility settles on titanium the best material decision for some basic applications. Albeit typically more grounded artistic materials have been grown, all around ceramic materials are not yet acknowledged as a restorative material. Since the achievement rate of ceramic materials in rebuilding dentistry relies upon clinician's capacity to choose suitable material to coordinate intraoral condition and stylish requests. Ceramics and other materials yet to be improved to use it in restorative dentistry in so many ways such as Biocompatibility, aesthetic appearance, mechanical properties, etc.

\section{REFERENCES}

[1] Gorga RE. Nanotechnology in textiles. Text World November/December 2010:3

[2] Chan C. From nanotech to nanoscience. Chem Heritage Mag 2008;26(2):2.

[3] Reibold M, Paufler P, Levin AA, Kochmann W, P€atzke N, Meyer DC. Discovery of nanotubes in ancient damascus steel. In: Physics and Engineering of New Materials. Springer Proceedings in Physics, 127; 2009. p. 305e10. 
[4] Ngo C, van de Voorde M. Nanotechnology in a nutshell: from simple to complex systems. Atlantis Press; 2014

[5] Taniguchi N. On the basic concept of 'Nano-Technology'. In: Proceedings of the International Conference on Production Engineering Tokyo, Part II, Japan Society of Precision Engineering; 1974.

[6] Binnig G, Rohrer H. Scanning tunnelling microscopy. Helv Phys Acta 1982;55 (6):726e35.

[7] Kroto HW, Heath JR, O'Brien SC, Curl RF, Smalley RE. C60: buckminsterfullerene. Nature 1985; 318(6042):162e3.

[8] Iijima S, Ajayan PM, Ichihashi T. Growth model for carbon nanotubes. Phys Rev Lett 1992;69(21): 3100e3

[9] Johnson, W. W. 1959. The History of Prosthetic Dentistry. The Journal of Prosthetic Dentistry, 9, 841-846.

[10] Kelly, J. R. 1997. Ceramics in Restorative and Prosthetic Dentistry1. Annu. Rev. Mater. Sci, 27, 443-68.

[11] Kelly, J. R., Nishimura, I. \& Campbell, S. D. 1996. Ceramics in Dentistry: Historical Roots and Current Perspectives. The Journal of Prosthetic Dentistry, 75, 18-32.

[12] Anusavice, K. J. 2003. Phillips' Science of Dental Materials, Saunders

[13] J.G. Ironside and M.V. Swain, Ceramics in Dental Restorations - A Review and Critical Issues, Journal of the Australasian Ceramic Society, Vol. 34 no. 2, pp. 7891 (1998).

[14] Zohaib Khurshid et al, Advances in Nanotechnology for Restorative Dentistry, Materials . 2015, 8, 717-731 ISSN 1996-1944.

[15] Henry A. Rodríguez et al, Development of mechanical properties in dental resin composite: Effect of filler size and filler aggregation state, https://doi.org/10.1016/j.msec.2019.03.090

[16] S.K. Sahoo, V. Labhasetwar, Nanotech approaches to drug delivery and imaging, Drug Discovery Today, 8 (2003) 1112-1120.

[17] O.C. Farokhzad, J. Cheng, B.A. Teply, I. Sherifi, S. Jon, P.W Kantoff, J.P. Richie, R. Langer, Targeted nanoparticle-aptamer bioconjugates for cancer chemotherapy in vivo, Proceedings of the National Academy of Sciences of the United States of America, 103 (2006) 6315-6320

[18] J.R. Morones, J.L. Elechiguerra, A. Camacho, K. Holt, J.B. Kouri, J.T. RamÃrez, M.J. Yacaman, The bactericidal effect of silver nanoparticles, Nanotechnology, 16 (2005) 2346-2353.

[19] S. Shrivastava, T. Bera, A. Roy, G. Singh, P. Ramachandrarao, D. Dash, Characterization of enhanced antibacterial effects of novel silver nanoparticles, Nanotechnology, 18 (2007).

[20] D.A. Pelletier, A.K. Suresh, G.A. Holton, C.K. McKeown, W. Wang, B. Gu, N.P. Mortensen, D.P. Allison, D.C. Joy, M.R. Allison, S.D. Brown, T.J. Phelps, M.J. Doktycz, Effects of engineered cerium oxide nanoparticles on bacterial growth and viability, Applied and Environmental Microbiology, 76 (2010) 7981-7989.

[21] Helmut Knosp,Richard J Holliday,Christopher W. Corti,R. J. Holliday, Christopher W Corti: Gold in Dentistry: Alloys, Uses and Performance, Gold Bulletin 2003 93-102.

[22] Van WykCw, Theunissen F. Phillips Vm. A Grave matter-dental findings of people buried in the 19th and 20th centuries-J Forensic Odontostomatol. Dec; 1990. 8(2): 15-30.

[23] Ferrier W.I. Use of gold foil in general practice.JADA May 1941 28: 691- 700 .

[24] Randall M. German 'Gold Alloys for Porcelain-Fused-to-metal Dental Restorations', , Gold Bulletin, 1980, 13 (2), 57-62

[25] Dr. Smita Govila*, Dr. minkle gulati "Old is Gold" - A Review on "Direct Filling Gold", IJRID Volume 2 Issue 6 Nov.-Dec 2012:917.

[26] J. A. Donaldson “The Use Of Gold In Dentistry An Historica Overview. Part I" British Dental Association Museum, London, U.K. Page N0 117-124.

[27] Ohta M, Shiraishi T, Yamane M. Phase transformation and agehardening of Au-Cu- Pd ternary alloys. Journal of Materials Science 1986;21(2) 529-535.

[28] Winn H, Tanaka Y, Shiraishi T, Udoh K, Miura E, Hernandez RI, Takuma Y, Hisatsune K. Two types of checkerboard-like microstructures in $\mathrm{Au}-\mathrm{Cu}-\mathrm{Pd}$ ternary alloys. Journal of Alloys and Compounds 2000;306(1-2) 262-269.

[29] Seol HJ, Son KH, Yu CH, Kwon YH, Kim HI. Precipitation hardening of a $\mathrm{Cu}$-free $\mathrm{Au}-\mathrm{Ag}-\mathrm{Pd}-\mathrm{In}$ dental alloy. Journal of Alloys and Compounds 2005;402(1-2) 130-135.
[30] Seol HJ, Shiraishi T, Tanaka Y, Miura E, Hisatsune K, Kim HI. Ordering behaviors and age-hardening in experimental $\mathrm{AuCu}-\mathrm{Zn}$ pseudobinary alloys for dental applications Biomaterials 2002;23(24) 4873-4879.

[31] Hisatsune K, Sakrana A, Hamasaki K, Hernandez R, Salonga JP Phase transformation in a dental gold alloy for soldering. Journal of Alloys and Compounds 1997;261(1-2) 308-312.

[32] Lee JH, Yi SJ, Seol HJ, Kwon YH, Lee JB, Kim HI. Age-hardening by metastable phases in an experimental $\mathrm{Au}-\mathrm{Ag}-\mathrm{Cu}-\mathrm{Pd}$ alloy. Journal of Alloys and Compounds 2006;425(1-2) 210-215.

[33] Osborne JW, Norman RD. 13-year clinical assessment of 10 amalgam alloys. Dent Mater 1990;6:189-94

[34] Letzel H, van't Hof MA, Marshall GW, Marshall SJ. The influence of the amalgam alloy on the survival of amalgam restorations: A secondary analysis of multiple controlled clinical trials. J Dent Res 1997;76:1787-98

[35] Berry TG, Osborne JW. Effect of zinc in two non-gamma-2 amalgam systems. Dent Mater 1985;1:98-100.

[36] Osborne JW, Berry TG. Zinc-containing high copper amalgams: A 3-year clinical evaluation. Am J Dent 1992;5:43-5.

[37] Moore P. Elements of Dental Materials for Dental Hygientists and Dental Assistants. 6th ed. USA: W.B. Saunders Company; 1994.

[38] Sarkar NK, Park JR. Mechanism of improved resistance of zinccontaining dental amalgams. J Dent Res 1988;67:1312-5.

[39] Yamada T, Fusayama T. Effect of moisture contamination on high copper amalgam. J Dent Res 1981;60:716-23.

[40] Osborne JW, Howell ML. Effects of water contamination on certain properties of high copper amalgams. Am J Dent 1994;7:337-41

[41] Ramesh Bharti, Kulvinder Kaur Wadhwani, Aseem Prakash Tikku, Anil Chandra, "Dental amalgam: An update" Journal of Conservative Dentistry | Oct-Dec 2010 | Vol 13 | Issue 4:204-208.

[42] Ring ME. Dentistry. An illustrated history. New York: Harry N Abrams, Inc.; 1985.

[43] Hoffmann-Axthelm W. History of dentistry. In: Koehler HM translator. Chicago: Quintessence; 1981. p. 43, 156.

[44] Campbell JM. Dentistry then and now. Glasgow: Bell and Bain; 1981. p. 265-6

[45] Amos Westcott. Metallic pastes for filling teeth. Am J Dent Sc $1844 ; 4: 211$.

[46] Evans TW, Messrs. Experimenting with cadmium in the tin mixture: Preserve the color better and absorbed the mercury. Vol. 3 Paris: White and Co., Dent Newsletter; 1849. p. 9.

[47] Black GV. An investigation of the physical characters of the human teeth in relation to their disease, and to practical dental operations, together with physical charecters of filling materials. The Dental Cosmos 1895;37:553-61,637-61.

[48] Black GV. The physical properties of the silver-tin amalgams Dental Cosmos 1896;38:965-92.

[49] Black GV. Operative Dentistry. 1st ed., Vol. 2. Chicago: MedicoDental Publishing Company; 1908.

[50] Mitra, S.B.; Wu, D.; Holmes, B.N. An application of nanotechnology in advanced dental materials. JADA 2003, 134 $1382-1390$

[51] Eley, B.M. The future of dental amalgam: A review of the literature. 2. Mercury exposure in dental practice. Br. Dent. J. 1997, 182, 293 297.

[52] Eley, B.M. The future of dental amalgam: A review of the literature. 4. Mercury exposure hazards and risk assessment. Br. Dent. J. 1997 $182,373-381$.

[53] Jones, D.W. A Canadian perspective on the dental amalgam issue. Br. Dent. J. 1998, 184, 581-586.

[54] Warfvinge, K. Mercury exposure of a female dentist before pregnancy. Br. Dent. J. 1995, 178, 149-152

[55] Smart, E.R.; Macleod, R.I.; Lawrence, C.M. Resolution of lichenplanus following removal of amalgam restorations in patients with proven allergy to mercury salts - a pilot-study. Br. Dent. J. 1995 $178,108-112$.

[56] Eley, B.M. The future of dental amalgam: A review of the literature 7. Possible alternative materials to amalgam for the restoration of posterior teeth. Br. Dent. J. 1997, 183, 11-14.

[57] Mclean, J.W. Alternatives to Amalgam Alloys: 1. Br. Dent. J. 1984 $157,432-433$. 
[58] Yardley, R.M. Alternatives to Amalgam Alloys: 2. Br. Dent. J. 1984, 157, 434-435.

[59] Saunders, S.A. Current practicality of nanotechnology in dentistry. Part 1: Focus on nanocomposite restoratives and biomimetics. Clin. Cosmet. Investig. Dent. 2009, 1, 47-61.

[60] William J. O'Brien Dental Materials and Their Selection - 3rd Ed. (2002)- ISBN 0-86715-406-3; Quintessence Publishing Co, Inc; page 317 , chapter -12 .)

[61] S. M. Dunne and R. Abraham Br Dent J "A study into the performance of a gallium-based restorative material"2000; 189: 310 313, BRITISH DENTAL JOURNAL, VOLUME 189, NO. 6, SEPTEMBER 23 2000. Pg.306.

[62] Sulekha Gosavi1, Siddharth Gosavi*1, Ramakrishna Alla2 "Titanium: A Miracle Metal in Dentistry" Trends Biomater. Artif. Organs, 27(1), 42-46 (2013)

[63] Lautenschlager E.P., Monaghan P. Titanium and Titanium alloys as dental materials. Int Dent J 43, 245 - 253 (1993).

[64] Frank, T.G., Xu, W., Cuschieri, A. (1997). Shape Memory Applications in Minimal Access Surgery - The Dundee Experience. Proc. Sec. Int.Conf. Shap. Mem. and Super. Techn., ed. A. Pelton, D. Hodgson, S. Russell, T. Duerig, 509-514

[65] International Titanium Association- Medical Data sheet

[66] McCracken M. Dental implant materials: commercially pure titanium and titanium alloys. J Prosthodont, 8:40-3 (1999

[67] Koenoenen M., Kivilahti J. Fusing of Dental Ceramics to Titanium. J Dent Res; 2001, 80, 848 - 854,

[68] Haasters, J., Salis-Solio, G., Bonsmann, G. (1990). The use of Ni-Ti as an implant material in orthopedics. Engineering aspects of shape memory alloys. T.W. Duerig, K.N. Melton, D. Stockel.

[69] Cutright et al. 1973, Iwabuchi et al. 1975, Castleman et al. 1976, Simon et al. 1977

[70] I. Dl.lerig TW, Pelton AR, Stockel 0 (1996) The utility of \$uperelutid ty in medidne. Biomed Mater Eng 6:255-266.

[71] Hauters J, Salis-Solio G, Bonsmann G (1990) The use of Ni-Ti as an implant material in orthoredics .In: Duerig TW, Melton KN, Stockel D,Wayman CM (tds) Engineering aspects of shape memory alloys. Butterworth-Heinemann, Boston, pp 426-444.

[72] A. M. Al-Mayouf, A. A. Al-Swayih, N. A. Al-Mobarak, and A. S. Al-Jabab, "Corrosion behavior of new titanium alloy for dental implant applications," The Saudi Dental Journal, vol. 14, no. 3, pp. $118-125,2002$

[73] M. Sharma, A. V. Ramesh Kumar, N. Singh, N. Adya, and B. Saluja, "Electrochemical corrosion behavior of dental implant alloys in artificial saliva," Journal of Materials Engineering and Performance, vol. 17, no. 5, pp. 695-701, 2008.

[74] Iijima M, Yuasa T, Endo K, Muguruma T, Ohno H and Mizoguchi I. Corrosion behaviour of ion implanted nickel-titanium orthodontic wire in fluoride mouth rinse solutions. Dental Materials Journal, 2010, 29(1): 53-58.

[75] ShermanWO.Vanadium steel bone plates and screws. SurgGynecol Obstet 1912;14(6):629-34.

[76] Strauss B. Steel alloy, 1,587,614. United States Patent Office; June 8,1926

[77] Anusavice KJ, Phillips RW. Phillips' science of dental materials. 11 th edition. St. Louis (MO): Saunders; 2003.

[78] Seale NS. The use of stainless steel crowns. Pediatr Dent 2002;24(5):501-5.

[79] Threlfall AG, Pilkington L, Milsom KM, et al. General dental practitioners' views on the use of stainless steel crowns to restore primary molars. Br Dent J 2005;199(7):453-5 [discussion: 441].

[80] Willmann G and Von Chamier W. Bioceramics in orthopedics: New applications. Stuttgart, Germany, Enke Verlag, 1998.

[81] Lawson NC, Burgess JO. Dental ceramics: A current review. Compend Contin Educ Dent, 2014

[82] Shenoy A, Shenoy N. Dental ceramics: An update. J Conserv Dent 2010; 13: 195-203.

[83] Denry I, Holloway JA. Ceramics for dental applications: A review. Materials, 2010; 3: 351-368.

[84] Dr Karishma Shah , Dr Abhilasha Bal “ Dental Ceramics- Past, Present And Future - Literature Review " Iosr Journal Of Dental
And Medical Sciences (Iosr-Jdms) Volume 15, Issue 3 Ver. Ix (Mar. 2016), Pp 32-39, E-Issn: 2279-0853, P-Issn: 2279-0861.

[85] JR Kelly, P Benetti, Ceramic materials in dentistry: historical evolution and current practice, Australian Dental Journal 2011; 56:(1 Suppl): 84-96.

[86] Plumb JH. In the Light of History. New York: Delta, 1971:59-65.

[87] Anusavice, K. J. 2003. Phillips' Science Of Dental Materials, Saunders.

[88] Dr Karishma Shah , Dr Abhilasha Bal “ Dental Ceramics- Past Present And Future - Literature Review " Iosr Journal Of Denta And Medical Sciences (Iosr-Jdms) Volume 15, Issue 3 Ver. Ix (Mar. 2016), Pp 32-39, E-Issn: 2279-0853, P-Issn: 2279-0861.

[89] Sulong MZ, Aziz RA. Wear of materials used in dentistry: A review of the literature. J Prosthet Dent 1990;63:342-9.

[90] Shellis RP, Addy M. The interactions between attrition, abrasion and erosion in tooth wear. Monogr Oral Sci 2014;25:32-45.

[91] Wiley MG. Effects of porcelain on occluding surfaces of restored teeth.J Prosthet Dent 1989;61:133-7.

[92] Bani D, Bani T, Bergamini M. Morphologic and biochemical changes of the masseter muscles induced by occlusal wear: Studies in a rat model. J Dent Res 1999;78:1735-44.

[93] Oh WS, Delong R, Anusavice KJ. Factors affecting enamel and ceramic wear: A literature review. J Prosthet Dent 2002;87:451-9.

[94] Ohlmann B, Trame JP, Dreyhaupt J, Gabbert O, Koob A Rammelsberg P. Wear of posterior metal-free polymer crowns after 2 years. J Oral Rehabil 2008;35:782-8.

[95] Levrini L, Di Benedetto G, Raspanti M. Dental wear: A scanning electron microscope study. Biomed Res Int 2014;2014:340425.

[96] Hanif A, Rashid H, Nasim M. Tooth surface loss revisited:Classification, etiology and management. J Res Dent 2015;3:37-43.

[97] Huysmans MC, Chew HP, Ellwood RP. Clinical studies of dental erosion and erosive wear. Caries Res 2011;45 Suppl 1:60-8.

[98] Kitasako Y, Sasaki Y, Takagaki T, Sadr A, Tagami J. Age-specific prevalence of erosive tooth wear by acidic diet and gastroesophageal reflux in Japan. J Dent 2015;43:418-23.

[99] Fadhel A. Al-Sanabani, Ahmed A. Madfa, Nasr H. Al-Qudaimi. Alumina Ceramic for Dental Applications: A Review Article. American Journal of Materials Research. Vol. 1, No. 1, 2014, pp. 26-34.

[100]Willmann G. Ceramic femoral heads retrievals data, Clinica Orthopedics, 2000; 379: 173-177.

[101]Willmann G and Von Chamier W. Bioceramics in orthopedics: New applications. Stuttgart, Germany, Enke Verlag, 1998.

[102]Lawson NC, Burgess JO. Dental ceramics: A current review. Compend Contin Educ Dent, 2014.

[103] Shenoy A, Shenoy N. Dental ceramics: An update. J Conserv Dent, 2010; 13: 195-203.

[104]Denry I, Holloway JA. Ceramics for dental applications: A review. Materials, 2010; 3: 351-368.

[105]Conrad HJ, Seong WJ, Pesun IJ. Current ceramic materials and systems with clinical recommendations: a systematic review. J Prosthet Dent 2007;98(5): 389-404

[106]Della Bona A, Kelly JR. The clinical success of all-ceramic restorations. J Am Dent Assoc 2008;139(Suppl):8S-13S.

[107] Al-Amleh B, Lyons K, Swain M. Clinical trials in zirconia: a systematic review. J Oral Rehabil 2010;37(8):641-52.

[108] Mahalick JA, Knap FJ, Weiter EJ. Occlusal wear in prosthodontics. J Am Dent Assoc 1971;82:154-9.

[109]Haroon Rashid Zeeshan Sheikh, Syed Misbahuddin, Murtaza Raza Kazmi, Sameer Qureshi, Muhammad Zuhaib Uddin, "In Advancements in all-ceramics for dental restorations and their effect on the wear of opposing dentition" European Journal of Dentistry, Vol 10 / Issue 4 / Oct-Dec 2016.

[110] Usha G, Prashanth T R, Roopa R Nadig, Yeshwanth Gowda and Murtuza, "Advanced ceramics - A review of material science" Journal of Dental Science and Research, Vol-5, Issue-2, Pages 5-11, Sept-2014. 